Zbornik Instituta za kriminološka

i sociološka istraživanja

2021 / Vol. XL / 2-3 / 91-104

Pregledni naučni rad

Primljeno: 1. 11. 2021. godine

Prihvaćeno: 23. 11. 2021. godine

DOI: $10.47152 /$ ziksi202123026

UDK: 159.942 .6

\title{
PSYCHOLOGICAL THEORIES OF AGGRESSION*
}

\author{
Nikola Drndarević ${ }^{*}$
}

\begin{abstract}
This paper aimed to provide a short exposition of the main theories of aggression. The choice of the theories reflected, in part, the historical progression and rising complexity of the theories over time. A brief overview of the following theoretical perspectives on aggression was presented: Freud's psychoanalytic theory; Lorenz's ethological theory; Behaviorist theory; Frustration-aggression hypothesis; Cognitive neoassociation theory; and Social learning theory. These theories are representatives of the traditional perspective, which posits that by piecing together fragments of data gained through research, we arrive at the truth about aggression. A radically different perspective was offered through the constructivist perspective, which argues that any theory is just one way of organizing the data. Drawing from personal construct theory, a different psychological perspective on aggression was proposed.
\end{abstract}

KEYWORDS: aggression / psychology / theory / traditional / constructivist

\footnotetext{
* This paper represents the result of author's engagement in accordance with the Working Plan and Programme of the Institute of Criminological and Sociological Research for 2021.

* Istraživač pripravnik, Institut za kriminološka i sociološka istraživanja, Beograd. E-mail: nikola.drndarevic@iksi.ac.rs
} 
Zbormik IKSI, 2-3/2021 - D. Drndarević

„Psychological Theories of Aggression”, (str. 91-104)

\section{INTRODUCTION}

Arising from everyday language, the term aggression poses problems with providing a scientific definition. In contrast to being a unitary phenomenon, aggression comprises several aspects to which different theories postulate different explanations.

People are labelled aggressive if they find themselves in conflict situations where they cut off other cars in traffic, yell or physically assault each other. Different types of harmful acts may not be viewed by everyone as aggression. For example, injuries that sports players receive during a game or in some cases even the killing of enemy soldiers in the military matters of war. The most recognizable form of aggression is violence, usually manifested in destructive action. Generally accepted definition of aggression refers to simply any behavior that harms or injures others (Buss, 1961), or that the acts classified as aggression must involve the intention of harm or injury to the others (Berkowitz, 1993). Provided definitions include a broad range of behavior: from those not including a harmful action (e.g. passive-aggressive behavior of intentionally withholding information from others) to acts of verbally or physically aggressive behavior and infliction of violence. Such a definition may sometimes not include what would generally be encompassed by the term of aggression. A different psychological perspective on aggression was offered later in the text - one that does not make an intention to harm a key characteristic in aggressive behavior.

Difficulties in defining aggression have been reflected in many disciplines trying to determine what the essence of aggression is. Among others, the wide range of disciplines includes psychology, biology, economy, political science, anthropology, criminology, and sociology. Each scientific discipline has its level of analysis and develops its own set of theories and methods intending to explain aggression. This article deals with theoretical issues related to psychological approaches to aggression.

Provided theories will be restricted by focusing on human aggression viewed from various psychological perspectives: biological/innate, external, drive, cognitive neoassociation, social learning theory, and personal construct theory. This overview is aimed at providing the broader strokes of possible approaches. Hence, it will not contain gender and sex differences, genetic "make-up", physiological, ethological, and social elements, which are included only as far as they represent integrative elements of the mentioned perspectives.

There was not enough space to provide an exhaustive review of some of the theories presented here. Furthermore, some of these theories evolved and incorporated new findings within their frameworks. Instead, the choice here was to present the historical significance and the general frames these theories utilize to provide evolution and research of aggressive behavior. The aim was not to describe these 
Zbornik IKSI, 2-3/2021 - D. Drndarević

„Psychological Theories of Aggression”, (str. 91-104)

theories in detail, which was bound to be incomplete, but rather to illustrate a progression of frameworks and offer a different perspective.

\section{PSYCHOLOGICAL THEORIES OF AGGRESSION}

The earliest and oldest theories viewed aggression as a part of the individual constitution. Such a perspective proposes that aggression cannot be eliminated but rather channeled in constructive or destructive ways. A major influence for this position stemmed from Sigmund Freud's psychoanalytic theory and Konrad Lorenz's ethological view of aggression.

\subsection{Freud's psychoanalytic theory}

Earlier theories of Freud suggest that human behavior and its variations stem from one basic drive - libido. Libido (life drive, sex drive) was conceived as a creational force, having its origin in the biological constitution of an individual. Any blocking or inhibition of such a drive would engender aggression (Freud, 1915). After World War I, Freud revised his theory and elevated aggression to a product of a newly introduced drive named death drive. In opposition to libido, the death drive was conceived as a destructive force, aiming at the disintegration and dissolution of the individual (Freud, 1920). In that manner, aggression would be a redirection to others what was originally self-directed destruction.

The main dynamic agents responsible for diverting this self-destructive force outward were displacement and sublimation. In both, the aggressive urges are acted upon. In displacement, the target of aggression is different, while in sublimation, the aggression is transformed into something socially acceptable. If death drive is not adequately dealt with, destructive energy will accumulate and result in destructive behavior. A possibility for tension reduction was also proposed in a notion of catharsis via non-harmful discharge.

Aggression was perceived as inherited and biological, which can be expressed overtly or covertly, internally or externally. Consequently, aggressive inclinations present in humans can never be completely uprooted (Freud, 1933). It should be noted that contemporary context holds not one psychoanalytic theory but rather psychoanalytic theory. A fundamental dispute is present between structural theorists, who tend to see aggression as a consequence of personality structure (e.g. Fromm, 1973), and self-psychologists, who tend to consider aggression as secondary to narcissistic injury (e.g. Kohut, 1972).

Numerous critiques were mounted on Freud's theory of aggression over the years (Pedder, 1992). Description of aggression as innate still lacks a concrete source for it, while at the same time bearing the characteristic of unfalsifiability. Furthermore, while certain aspects of his theory were based on clinical material, other aspects were more intellectual speculation, especially pertinent to the death drive theory of aggression. Generalizations are further restricted by the sample of his patients that usually consisted of middle-class pathologies of the Victorian era. The notion of 


\author{
Zbornik IKSI, 2-3/2021 - D. Drndarević \\ „Psychological Theories of Aggression”, (str. 91-104)
}

catharsis as a control mechanism for decreasing aggression is controversial. Finally, little attention was given to the role of the environment and its effects on aggressive behavior, as well as the deterministic nature of aggression that contains little room for the idea of the free will of an individual.

\title{
2.2. Lorenz's ethological theory
}

Another proponent of aggression as innate was Konrad Lorenz, a Nobel-prized ethologist. Lorenz proposed a definition of aggression as the fighting instinct present in both animals and humans, directed against members of the same species (Lorenz, 1966; 1974). Aggression arises from a fighting instinct, which human beings share with other species. Such an idea is an extension of Darwinian "struggle for existence" according to which nature favors the stronger individual in the end.

Based on his scientific studies of animal behavior, aggression was seen as a positive and adaptive instinct. Aggression regulates nature-order balance, ensures the continual selection of genes towards strength, and increases the likelihood of survival for offspring. Aggression is further viewed as crucial to advancing social life and structuring social hierarchy. In Lorenz's view, aggression takes on a form of a true and preserving instinct.

On the other hand, the energy associated with this instinct is spontaneously produced in individuals at a more or less constant rate. The probability of aggression behavior increases as a function of the amount of stored energy and the presence and strength of aggression releasing stimuli. Aggression is viewed as inevitable and may at times erupt in spontaneous outbursts of powerful feelings. Aggression is thus also an animal-type behavior leftover from our ancestors from our pre-cultural past and thus not necessarily conducive to civilized life.

Lorenz was extensively criticized on several fronts (Fromm, 1973). The most noteworthy critique was aimed at his unjustified extrapolation from animal to human aggression. Animal aggression is mostly dependent and regulated by immediate changes in the stimulus, while human aggression is (as any behavior) much less bound to stimulus. Moreover, the unidimensional nature of such aggression is further open to criticism. Human aggression contains nuances that are not encompassed by the definition provided by Lorenz. Any act of violence is a consequence of biological constitution. Violence in wars, criminal behavior, personal and social conflicts, or any destructive behavior is an expression of built-up aggression. Without an adequate discharge stimulus, it will spontaneously break out in dangerous ways. Lorenz's theory offers a simple explanation for human aggression becoming thus a rationalization and an excuse for aggressive behavior.

Summary: Due to its logical consequences, the framework of aggression as innate implies the impossibility of aggression elimination. Aggressive impulses are inevitably bound to exist, irrespective of satisfaction of material needs, elimination of social injustice, or any positive changes in social structures. The best one can hope for is a temporary inhibition of such behavior or reduction of its intensity. Aggressive impulses are continually generated from an unextinguishable source within the 
Zbornik IKSI, 2-3/2021 - D. Drndarević

„Psychological Theories of Aggression”, (str. 91-104)

individual and will threaten to erupt unless continually released. Aggression is thus ineradicable in being an integral part of human beings.

\subsection{Behavioristic perspective}

In contrast to theories that view aggression as internally generated, the behavioristic perspective views aggression as externally caused. The key idea that governed behaviorism was that the object of scientific research should be only that which can be directly observed - the behavior of humans. All else (meaning primarily internal events such as feelings, intentions, wishes...) should be removed from scientific study. In line with this postulate, the behavior of people is determined and molded by the environment, not the inborn psychological traits. Aggression from a behavioristic perspective is viewed as an acquired behavior. The main mechanism responsible for the acquisition of any behavior is operant conditioning (Skinner, 1953). If the behavior resulted in some kind of reward, this was designated as positive reinforcement. In other words, if manifesting aggressive behavior results in being rewarded (toy, candy, money, social status, or even removal of aversive stimuli), then this behavior is reinforced. In turn, it increases the likelihood that the individual would behave in that way again in the future.

The main problem with the purely behavioristic approach to human behavior is that it falls short in explaining how individuals come to behave in particular ways when they have received no previous reinforcement for that behavior. Furthermore, not everyone uses aggressive behavior even if they receive positive reinforcement. In essence, the behavioristic perspective provides a one-dimensional approach, but this time, through external stimuli instead of internal forces.

\subsection{Frustration-aggression hypothesis}

An attempt to both address the limitations of previous approaches as well as to bridge the gap between psychoanalysis and behaviorism was presented in the frustration-aggression hypothesis (Dollard, Doob, Miller, Mowrer \& Sears, 1939; Miller, 1941). This perspective aimed at reinterpreting psychoanalytic theory in terms of stimulus-response, which could generate more empirically testable behavioral propositions.

Aggression is conceived as the aggressive drive rather than the aggressive instinct. Such a drive is induced rather than inborn. The forming of the drive is in connection to the external stimuli, which blocks or inhibit the goal-directed behavior. The result is frustration, which elicits an instigation toward aggression, i.e. aggressive drive. Aggression is thus the reaction to frustration. Other reactions to frustration are also possible, but aggression is the fundamental reaction. The expression of aggression would reduce the desire for it, in turn. The strength of the aggressive drive varies according to three variables: the amount of frustration, degree of interference with goal-directed behavior, and many frustrated responses experienced by the individual. Similar to innate models, the aggression may be stored and compounded with each new frustration, due to learned inhibitions (e.g. punishment or fear of 


\section{Zbornik IKSI, 2-3/2021 - D. Drndarević \\ „Psychological Theories of Aggression”, (str. 91-104)}

punishment) and may later be displaced on a powerless or a less powerful stimulus. The potential to aggress is inborn, but it necessitates frustrating stimuli to initiate a response, thereby designating aggression as a reactive phenomenon. No primacy of either genetics or environment is emphasized in the etiology of aggressive behavior.

In contrast to theories of aggression as innate and constitutional, the strongest asset of the frustration-aggression hypothesis was its ability to subject the causative variables to empirical investigation and intensive scientific scrutiny. This produced a great amount of research that also discovered its weak points. The weak point was the formulation that frustration was a necessary instigator of aggressive behavior. Frustration is only one among various antecedents that may lead to aggression and aggression itself can be used instrumentally and does not have to be only a reaction to frustration (Berkowitz, 1962; Buss, 1961). Consider the example of a pilot bomber whose actions may be described as aggression, and yet his motivation lies in the successful completion of the mission and not necessarily the result of being frustrated. Furthermore, not all frustrated individuals engage in verbal or physical assaults against others. The reaction to frustration may sometimes be resignation, despair, or an active attempt to overcome the obstacles that stand in the way. Consider the example of being rejected entrance to various universities, which could engender frustration, but a depressive response, rather than the aggressive one may follow. Finally, a situation considered frustrating for one person may not be frustrating for another person.

The frustration-aggression hypothesis proved to be a limiting and simplistic view of a complex behavior such as human aggression. Such a theory provides us with a deterministic explanation that removes attention from the role the individual might play in their aggression and the needs of the social environment within which they interact. Out of the frustration-aggression hypothesis, more sophisticated versions emerged that were modified and enriched in time.

\subsection{Cognitive-Neoassociation Theory}

Another critique of the frustration-aggression hypothesis came from Leonard Berkowitz (1962, 1989, 1993, 2012). Berkowitz introduced several modifications to this theory, out of which the focus will be placed on two that are relevant to the aim of the paper.

The first modification concerned the presence of aggressive cues as a necessary condition for aggressive behavior (Berkowitz, 1962; 1989). Frustration, according to Berkowitz, is not a sufficient condition for aggressive behavior. Frustration induces a negative emotional reaction, anger, which creates only readiness for aggressive behavior. Successively, such behavior will be manifested only when suitable aggressive cues associated with anger or aggression are present. Thus, frustration is viewed as an aversive event that causes aggression if it is accompanied by negative affect.

The second modification is of recent date and concerns the remodeling of the initial modification and introduction of cognitive factors. This theory was named a 


\author{
Zbornik IKSI, 2-3/2021 - D. Drndarević \\ „Psychological Theories of Aggression”, (str. 91-104)
}

cognitive-neoassociation theory (Berkowitz, 2012). According to this theory, when a provocative event occurs, the negative affect is experienced. A negative affect triggers lower-order associations that trigger fight-or-flight memory networks. Which tendency, i.e. association network, will be triggered depends on various factors, including genetic make-up of the individual, acquired responses, and the situation. If the fight tendency activates more strongly, the individual experiences anger resulting from the awareness of fight-related reactions. Otherwise, if the flight tendency actives more strongly, the individual experiences fear and flight-related reactions. In other words, if a memory network related to aggression is activated, an individual generates a hostile explanation for the triggering situation, which culminates in aggressive behaviors toward the target.

The individual also has access to higher-order cognitive processing regarding the consequences of their action, the intensity of which depends on the circumstances. Such cognitions can lead to increased or decreased aggression by enabling the individual to reassess the situation. It should be noted that higher-order cognitions are not necessary for aggression to occur and are secondary to the experienced affect.

\title{
2.6. Learned Social Behavior
}

Several authorities on aggression (e.g. Bandura, 1973; Buss, 1961; Zillmann, 1988) criticized earlier theories of aggression in which their main attack point was that aggression potentially encompasses various antecedents and not necessarily a single factor such as frustration. Albert Bandura was the most influential proponent of learned social behavior as a framework for understanding aggression.

Bandura was not completely satisfied with the classic behavioristic thesis of trialand-error processes being responsible for learning behaviors. Although approving of this thesis, his studies of learning in interpersonal contexts suggested that operant conditioning was not enough to account for behavior that had not yet been learned. He suggested that another process is even more crucial - social learning (Bandura, $1973 ; 1977 ; 1986)$. Specifically, the attention was directed to the fact that human beings frequently acquire many new forms of behavior, including patterns of aggression, through observation of the actions and outcomes of others. A large number of empirical data supported his hypothesis. By simply observing the behavior of other persons, children or adults readily acquire novel behavior responses, including aggression. Consequently, aggression is imitated and exposure to the models of imitation is a basic requisite for any kind of model learning. Four factors are necessary for the imitation to take place: attention (to the model of aggressive behavior), retention (encoding of the model's behavior), reproduction (imitating the model), and motivation (optimal reason for imitation). Accordingly, the role of conditioning is not removed, but rather a part of the social learning process.

Despite being heavily supported by empirical data, social learning is criticized (Tedeschi \& Felson, 1994) for limiting generalizability outside a laboratory setting 


\author{
Zbornik IKSI, 2-3/2021 - D. Drndarević \\ „Psychological Theories of Aggression”, (str. 91-104)
}

thereby underestimating the relevance and pervasiveness of social context. Furthermore, it is unclear regarding the mechanisms responsible for modeling effect. What type of model achieves what effect, on what kind of individuals, under what circumstances?

Viewing aggression through the lens of learned social behavior opens the possibility of direct modification and reduction via many procedures. Such an approach does not consider human beings as driven toward aggression by in-built internal forces or ever-present external stimuli (e.g. frustrating events or rewarded behavior). The focus is rather placed on social conditions that facilitate such behavior. Aggression can thus be prevented or reduced by altering such conditions. Theoretical frameworks viewing aggression as a learned form of social behavior have been gaining increasing acceptance in recent years, especially because of their empirical support of basic tenets. In contrast to other perspectives, it is also considerably more optimistic when considering the possibility of preventing and controlling aggressive behavior.

Summary: A retrospective overview of the psychological theories of aggression and their historical evolution presented a certain pattern. The first theories focused on biological underpinnings of aggression. The opposite stance within the behavioristic tradition emphasized the environment and the stimulus in the shaping of aggressive behavior. In the midst of opposing frameworks, while trying to reconcile psychoanalytic and behavioristic traditions, emerged frustration-aggression hypothesis, which eventually proved to be limited and simplistic as well. On the other hand, the frustration-aggression hypothesis provided a much-needed impetus for empirical research, which surpassed itself with more advanced and complex theories. The cognitive neo-association and social learning theories were presented which subsume both biological and environmental factors, with the supplement of cognitive and social factors. These contemporary theories provide us with a more comprehensive frame for explaining the complex behavior of human aggression.

Theories presented in previous pages can be grouped in a traditional perspective, within which a scientific venture embodies the search for the truth (Kuhn, 1996). By piecing together little fragments of the truth through numerous empirical experiments, we arrive at a truth about human behavior - in this case, aggressive behavior. Progression of theories, evident in the evolution of psychological theories of aggression, implies that we may be coming closer to this truth.

There is a different way to construe this evolution and progression of theories. In contrast to the traditional perspective, a constructivist perspective adopts a different position (Stojnov, 2011). Instead of piecing together parts of data on a road to truth, the constructivist perspective advocates that a theory is a way of interpreting the data, which is only one of many different ways of looking at the same data. The truth about aggressive behavior is not something that can ever be ascertained. Rather the validity of the theory rests on its fertility to generate further research and practical guidelines it provides. With each new theory of aggression, there is a shift in the framework of interpretation of observational and empirical data, and consequently a shift of pragmatic value of the theory (Kuhn, 1996). Consider the difference between 
Zbornik IKSI, 2-3/2021 - D. Drndarević

„Psychological Theories of Aggression”, (str. 91-104)

biological/innate theories and social learning theories about aggression. Within the innate theories about aggression, there were little or no practical guidelines available to affect effectively the reduction of aggression in society. With the social learning theories, we can focus our attention on models for emulation. Finally, a constructivist perspective could offer a perspective on aggressive behavior through some of its theories.

\subsection{Personal construct theory}

George Kelly $(1955,1969)$ expounded personal construct theory that aimed at being a comprehensive personality theory, posing radical views on psychology and consequently aggression. The person, in his theory, is always directed toward the future in an active attempt to anticipate the events. With this aim in mind, the person construes, much like a scientist, his theories about the world. These theories are then subjected to experimental evidence and are either validated or invalidated. Validation of such theories proves that the theory is useful in predicting the events, even though it may not necessarily reflect the reality or the truth of the phenomena. Invalidating evidence calls for the reconstruction of theories.

The theories with which the person manages to anticipate events are called constructs, which contain meanings that govern all behavior. The construct encompasses in itself motivations, emotions, and cognition and represents an avenue through which a person can move and act, feel, and reason. By wanting to understand the behavior of the person, we need to know the personality structure (their theory, their construing) that stands at the root of a given behavior. This introduces a paradoxically radical perspective, which focuses on the person and their view, instead of the view from the objective position trying to explain the observed behavior.

Such a stance provides an interesting critique of the traditional view of aggression. In naming any act that is damaging to the other person as aggression, the aggressive motive behind the act is rendered irrelevant. The roots of aggression cannot be understood without discriminating the motive from the damage that is caused. If we want to understand aggression, according to Kelly, we need to understand the actor and not the consequences of the act. This is not to say that the consequences are irrelevant, rather that they belong to other domains such as sociological or moralistic. If we want to understand the psychology behind aggressive behavior, we need to understand the construing, the meaning behind it. Instead of asking, the question of who injured whom, the better question, from the perspective of personal construct theory, is the question of what does the person wants to achieve with the behavior that is construed as aggressive.

Personal construct psychology also recognizes a difference between what could be considered healthy and pathological aggression. Healthy aggression bears more resemblance to initiative and adventuresomeness. The person who is aggressive in such a way is actively elaborating their theories/construing. In this way, the person is experimenting rapidly and turns up a large amount of data. This data may prove to 


\section{Zbornik IKSI, 2-3/2021 - D. Drndarević \\ „Psychological Theories of Aggression”, (str. 91-104)}

be invalidating to other people. Consequently, the behavior of this person is labeled as aggressive and anti-social because it is construed by other people as threatening. Consider for a moment introduction of novel knowledge by Galileo to reigning religious dogma of that time (Dawes, 2016). These examples may amount to the invalidation of some core theories/values and threaten the collapse of the status quo. From the perspective of the person being invalidated, this may be construed as a destructive act and intent and equated with hostility. When under threat, healthy aggression and pathological aggression (hostility) become equated.

Hostility cannot be defined as having an anticipated effect on someone within the personal construct theory. Rather, what is at stake in the person's own life is what is of importance. Hostility always involves other people but the damage or injury inflicted upon another person is not the primary goal of the individual, but rather incidental to something more vital that they are trying to achieve. If other people are not behaving the way the person expected, they will be made to behave that way - by any means. Violence may be the means of achieving respectful behavior from your companions and/or other people.

Having this framework in mind, one gets the impression that a broad range of behavior is packed into an everyday term of aggression. Aggressive behavior may be a side consequence of the way of life of an individual. Consider the case of Adolf Eichmann who was part of the Nazi SS and one of the major organizers of the Holocaust who was tried in Jerusalem and whose analysis was provided by Hannah Arendt (1964). Eichmann personally never had anything against the Jews. No sign of mental illness was recorded. Instead, he had a great need of belonging to a group. Not belonging was experienced as insufferable. Accordingly, he did whatever was necessary to uphold that standard. His actions were seen as validating his role of a good bureaucrat following orders within a group. Mass casualties were incidental and not construed as his aim or his responsibility. Such examples would fall under the category of what Arendt would call the "banality of evil". The lives that are ruined are collateral damage and mostly removed from thoughts.

Destructive intent is only one theme within the broader scope of complex human behavior of aggression. The subjectivist perspective provides us with a different picture of what aggression could contain, and what reasons stand behind aggression. This also points to the direction of necessary education of the incidental consequences to one's action. Becoming more aware of one's anticipations and what one's behavior is aiming at, could result in lowering the amount of suffering the people experience. This also complicates the picture of aggression. Many nuances need to be parsed out that are found in one general term of aggression.

However, personal construct theory offers very little a priori knowledge about aggression. The theory is highly formalistic, which entails that content needs to be generated in the present. Consequently, this theory offers a minimal amount of guidance to action to parents, researchers, society, or others who are trying to understand specific human behavior. The broad, highly abstractive, and formalistic nature is both the benefit and the cost of this theory. This is also the 


\author{
Zbornik IKSI, 2-3/2021 - D. Drndarević \\ „Psychological Theories of Aggression”, (str. 91-104)
}

reason why this theory is most applicable within the psychotherapeutic setting and other approaches dealing primarily with the individual level of analysis.

\title{
3. CONCLUSION
}

In the preceding pages, we have attempted to briefly outline the psychological theories of aggression and the way they progressed over time. It should be noted once more that a detailed and updated description of every theory was not feasible and was not required for the aim of this paper.

Each of the perspectives presented here stands predominantly on certain ground. Freud's psychoanalytic theory and Lorenz's ethological theories were chosen as representatives of constitutional and innate theories of aggression. Aggression was envisioned as biologically rooted behavior, which could be stored and threatened eruption unless modulated. At the other end were behaviorists, advocating for environmentalist causes of aggression. Aggressive behavior was acquired through operant learning, i.e. being positively reinforced. Overcoming the flaws of and trying to reconcile each theory, the frustration-aggression hypothesis sought to provide a more empirically testable theory that was seductive in its simplicity. As with any good scientific theory, it provided evidence of its limitations. Out of critiques of the frustration-aggression hypothesis, social learning theory and cognitive neoassociation theory of aggression emerged. Both theories have included, on top of biological and environmental factors, cognitive and social factors participating in the etiology of aggressive behavior.

The aggressive behavior that is the object of scientific study has not changed. Theories explaining the behavior, on the other hand, have changed. Each theoretical framework brings forth a new angle of rearranging the data, which would depend on the aim, serve a different purpose. This is the stance of the constructivist perspective, which functions as a metatheory. In other words, a theory is a useful tool helping us make sense out of the data and helping guide our understanding and behavior. Constructivist perspective on aggression was also offered through personal construct theory.

The main critique directed toward the traditional perspective was that the act alone, without the actor, no matter how scientific, cannot be optimal for analyzing human behavior. The starting point should be the subjective perspective, the perspective of the individual. The question is not why is the person acting aggressively, but rather what is the person trying to achieve with their behavior. Personal construct theory views aggression as either a testament to the audacity of the human spirit (healthy aggression) or a way of distorting the data (pathological aggression). The consequences to the other people are secondary to the primary aims of validation of a person's theories. The many examples of banalities of evil around us would be better understood starting from such a perspective. People who are labeled as aggressors are not being privy to the atrocities they make. All they did was preserve their way of life (Kelly, 1969). 


\author{
Zbornik IKSI, 2-3/2021 - D. Drndarević \\ „Psychological Theories of Aggression”, (str. 91-104)
}

The underlying philosophical aspects of these two perspectives are comparatively different. Traditional psychology assumes objective and essentialist metaphysics, in contrast to subjective and relational metaphysics of the constructivist paradigm. These differences constitute dissimilar frameworks within which different theories about aggression arise. In traditional psychology, the search is directed toward innate characteristics, personality traits that are present in all people, where the differences are reflected only in quantitative aspects. The goal is to grasp the essence of aggression within a person. In constructivist psychology, the search is directed toward relational characteristics, where the differences are reflected in qualitative aspects. The goal is to grasp the structure, which allows for a relational behavior that we label as aggression.

In contrast to saying that aggression exists and that it is evil by itself, the constructivist perspective asserts that the behavior is always present, but the construction of it may differ. If we want to understand the behavior from the perspective of the doer, of the actor, we need to understand the actor, and not the victim of such behavior. This is not to say that the effects of behavior are not morally, socially, or criminologically relevant. It is rather that if we want to understand the psychology of a person whose act is characterized as aggressive, we need to understand what that person is trying to achieve.

\title{
REFERENCES
}

(1) Arendt, H. (1964). Eichmann in Jerusalem: a report on the banality of evil. Rev. and enl. ed. Viking Press.

(2) Bandura, A. (1973). Aggression: A Social Learning Analysis. Prentice-Hall. http://dx.doi.org/10.2307/1227918

(3) Bandura, A. (1977). Self-efficacy: Toward a unifying theory of behavioral change. Psychological Review, 84(2), 191-215. https://doi.org/10.1037/0033295X.84.2.191

(4) Bandura, A. (1986). Social foundation of thought and action: A social cognitive theory. Prentice-Hall.

(5) Berkowitz, L. (1962). Aggression: A social psychological analysis. McGraw-Hill.

(6) Berkowitz, L. (1989). Frustration-aggression hypothesis: Examination and reformulation. Psychological Bulletin, 106, 59-73. https://doi.org/10.1037/00332909.106.1.59

(7) Berkowitz, L. (1993). Aggression: Its causes, consequences, and control. McGrawHill.

(8) Berkowitz, L. (2012). A cognitive-neoassociation theory of aggression. In P. A. M. Van Lange, A. W. Kruglanski, \& E. T. Higgins (Eds.), Handbook of theories of social psychology (pp. 99-117). Sage Publications Ltd. https://doi.org/10.4135/9781446249222.n31

(9) Buss, A. H. (1961). The psychology of aggression. Wiley. http://dx.doi.org/10.1037/11160-0oo

(10) Dawes, G. W. (2016). Galileo and the conflict between religion and science. Routledge. http://dx.doi.org/10.4324/9781315637723

(11) Dollard, J., Doob, L. W., Miller, N. E., Mowrer, O. H., \& Sears, R. R. (1939). Frustration and aggression. Yale University Press. http://dx.doi.org/10.1037/10022-000 


\author{
Zbornik IKSI, 2-3/2021 - D. Drndarević \\ „Psychological Theories of Aggression”, (str. 91-104)
}

(12) Freud, S. (1915). Instincts and their vicissitudes. In J. Strachey (Ed.), Complete psychological works of Sigmund Freud (vol. 14). Hogarth.

(13) Freud, S. (1920). Beyond the pleasure principle. In J. Strachey (Ed.), Standard edition of the complete psychological works of Sigmund Freud (vol. 18). Hogarth.

(14) Freud, S. (1933). Why War?. The Standard Edition of the Complete Psychological Works of Sigmund Freud, Volume XXII (1932-1936): New Introductory Lectures on Psycho-Analysis and Other Works, 195-216.

(15) Fromm, E. (1973). The anatomy of human destructiveness. Macmillan. http://dx.doi.org/10.1525/9780520949454-044

(16) Kelly, G. A. (1955). The psychology of personal constructs. New York: Norton (republished by Routledge, 1991). http://dx.doi.org/10.4324/9780203405987

(17) Kelly, G., \& Maher, B. A. (1969). Clinical psychology and personality: The selected papers of George Kelly. Wiley.

(18) Kohut, H. (1972). Thoughts on narcissism and narcissistic rage. The psychoanalytic study of the child, 27(1), 360-400. https://doi.org/10.1080/00797308.1972.11822721

(19) Kuhn, T. S. (1996). The structure of scientific revolutions. University of Chicago Press. http://dx.doi.org/10.7208/chicago/9780226458106.001.0001

(20) Lorenz, K. (1966). On aggression. New York: Harcourt, Brace, \& World.

(21) Lorenz, K. (1974). Civilized man's eight deadly sins. New York: Harcourt Brace Jovanovich.

(22) Miller, N. E. (1941). The frustration-aggression hypothesis. Psychological Review, 48(4), 337-342. https://doi.org/10.1037/hoo55861

(23) Pedder, J. (1992). Psychoanalytic views of aggression: some theoretical problems. British journal of medical psychology, 65(2), 95-106. https://doi.org/10.1111/j.2044-8341.1992.tbo1690.x

(24) Skinner, B. F. (1953). Science and human behavior. Macmillan.

(25) Stojnov, D. (2011). Od psihologije ličnosti ka psihologiji osoba. Beograd: Mediterran.

(26) Tedeschi, J. T., \& Felson, R. B. (1994). Violence, aggression, and coercive actions. American Psychological Association. https://doi.org/10.1037/10160-00o

(27) Zillmann, D. (1988). Cognitionexcitation interdependences in aggressive behavior. Aggressive Behavior, 14(1), 51-64. https://doi.org/10.1002/10982337(1988)14:1<51::AID-AB2480140107>3.0.CO;2-C 


\section{PSIHOLOŠKE TEORIJE O AGRESIJI}

Cilj ovog rada bio je da ukratko izloži glavne teorije agresije. Izbor teorija je delimično odražavao istorijski napredak i rastuću kompleksnost teorïa tokom vremena. Predstavljen je kratak pregled sledećih teorijskih perspektiva o agresiji: Frojdova psihoanalitička teorija; Lorencova etološka teorija; bihevioristička teorïa; hipoteza frustracije-agresije; kognitivna teorïja neoasocijacïje; $i$ teorija socijalnog učenja. Navedene teorije pripadaju okviru tradicionalne perspektive, koja polazi od pretpostavke da grupisanjem podataka dobijenih pojedinačnim istraživanjima dolazimo do istine o agresīi. Radikalno drugačija perspektiva ponuđena je kroz konstruktivističku perspektivu, koja turdi da je svaka teorija samo jedan od mogućih načina organizovanja podataka. Polazeći od teorije ličnog konstrukta, predložena je drugačija psihološka perspektiva o agresiji.

KLJUČNE REČI: agresija / psihologïa, teorïa / tradicionalna / konstruktivizam 